\title{
Effect of Colleague Context and Faculty Size on Scientific Productivity
}

\author{
Don M. Baridam ${ }^{1} \quad$ Letam Q. Don-Baridam ${ }^{2}$ \\ 1. Department of Business Administration, Faculty of Management Sciences, \\ Akwa Ibom State University, Obio Akpa Campus, P.M.B. 1167, Uyo, Akwa Ibom State Nigeria \\ 2. Department of Management, Faculty of Management Sciences, Rivers State University, Port Harcourt, \\ Nigeria
}

\begin{abstract}
The objective of this study was to find out the influence colleague context and faculty size on scientific productivity among lecturers in Administrative Sciences. Data were obtained from 176 faculty members in Administrative Sciences drawn from 11 Universities in Quebec Canada. The result of our findings showed positive and significant relationship between contacts with colleagues on research matters and single, multiple authored articles in refereed journals and multiple authored chapters in books. There was positive though, no significant relationship between colleague context and total articles and total book production. The result also revealed that aside the positive and significant relationship between faculty size and the production of single authored chapters in books, all other publication production measures did not have any significant relationship with faculty size. Based on these findings, it was concluded that colleague context and faculty size are not very good predictors of publication production in the faculties of administrative sciences. The implications for this study along with some directions for further study are addressed,
\end{abstract}

Keywords: Scientific productivity, colleague context, faculty size.

DOI: $10.7176 / \mathrm{EJBM} / 13-14-02$

Publication date:July $31^{\text {st }} 2021$

\section{Introduction}

There are very few studies on the effect of colleague context and faculty size on scientific performance (Min and Yong 2014, Hesli and Lee, 2011, Carayol and Matt, 2006, Welsch and Zimmer, 2016). Even in these few studies there is no significant study on the effect of colleague context and faculty size on scientific productivity in administrative sciences. The cognitive structure of scientific fields differs. Fields in the physical and chemical sciences like physics, and chemistry, have what Kuhn (1970) calls highly developed paradigms. Empirical knowledge in these fields is compacted, and precise; therefore, graduate students can discover quickly the current state of their field from textbooks and can commence work on the research frontiers while still graduate students. This is not the case in fields like administrative sciences, zoology and biology, which have less developed paradigms, since more experience is required to gain competence.

Giving the cognitive structure of the field of administrative sciences, the objective of this study is to find out the influence of colleague context and faculty size on scientific productivity.

\section{Review of Literature}

2.1 Colleague Context and Scientific Productivity: Colleague context arises as a result of common exposure of organizational members to the same objective structural characteristics, selection, attraction, and attrition of organizational members; and social interaction leading to shared meaning (Glick, 1985:604). This process can be likened to what organizational behaviorists have termed newcomer socialization- the period of time during which new organizational members know more precisely what is expected of them and what organizational membership has to offer (See Schein, 1971, Wanous, 1980); the sensemaking activities that newcomers engage in, in an attempt to organize the new stimuli they are exposed to into some personally meaningful structure (Louis, 1980:226).

Borrowing from the socialization literature, faculty members' identities or social selves change as they begin to interact with colleagues within the faculty and adopt the attitude of the colleagues towards the activities that go on within the group. Such interactions with colleagues help them understand the meaning of various aspects of the work context. Thus, a faculty member's decision to engage or not to engage in publication production will, among other things, depend upon the way his or her colleagues perceive scientific productivity. Min and Yong (2014:1987) maintain that "in the same organization, employee subjective perception among colleagues care and support is an important factor affecting work efficiency; the colleague mutual concerns will inspire each other's work enthusiasm, enhance the 'home' identity atmosphere, which helps to mobilize the enthusiasm of the staff work." Similarly, Nijhof, et.al. (2006), Schepers and Van den Berg, (2007) opined that the level to which coworkers' behaviour produces reinforcement for other employees affect their performance.

Anderson and Murray (!971) assert that ideas cannot be born, nurtured and refined within a single mind, 
thus the need to test ideas through communication among colleagues is a necessary impetus to publication activity and involvement. Similarly, Blau (1973), maintain that whether a faculty member's research interest is stimulated or stifled in an academic institution depends on his colleagues, on how many of them have completed graduate education, which has socialized as well as trained them for research. Colleagues with research skills, Blau continues, facilitate one's own research by tending to give advice when needed.

According to Pelz and Andrew (1966) scientific productivity is associated with scientists' communication among colleagues. The measure of communication according to them include contacts through memos and meetings, as well as conversation, and productivity held even after controlling for experience and supervisory status. Communication enhances performance, the authors maintain, because it provides ideas, help detect errors and promotes competition and rewards.

Given the importance of colleagues with respect to scientific productivity, it would be necessary to ask: Does it matter how often a faculty member in administrative sciences contact his or colleagues? Or phrasing the question differently, is the presence of colleagues a necessary condition for scientific productivity in administrative sciences?

Any attempt to answer this question requires a recapitulation of the epistemological nature of scholarly activity in administrative sciences. Scientific fields according to Lodahl and Gordon (1972:59) vary in their degree of development or maturity. In some scientific fields, scientists are more uniform in their practice than in others. This uniformity stems from the fact that their field has a larger body of generally accepted theories and agreed-upon strategies and paradigms upon which to base their present investigations. Unfortunately, however, administrative sciences do not have well-defined paradigms and thus, no uniformity in scientific practice. The differentiated nature of administrative sciences ensures that "the particular professional subgroup within it will each subscribe to somewhat different sets of norms considered appropriate to the extra scientific dealings of its members" (Robbins and Johnston, 1976:353).

In so far as we recognize the importance of colleagues with respect to scientific productivity, one nagging question remains; If a faculty member sees many colleagues within his or her own department, does it matter how many he sees outside? Studies reveal that three to four contacts with colleagues both within and outside the faculty member's local group would have a stimulating effect on scientific productivity (See Pelz and Andrews, 1966, Blau, 1976).

We should, however, not fail to mention that contacts with colleagues may be counterproductive for intellectual stimulation if the colleagues are not fully committed to scholarship, and do not hold divergent ideological views.

Based on the above discussions, the following hypothesis is posed:

1. There will be a positive and significant relationship between contacts with colleagues on research related matters and scientific productivity.

2.2 Faculty size and Scientific Productivity: Size is one of the prominent characteristics of the institutional context of scientific productivity. Its effects have been investigated in numerous studies (see Carayol and Matt, 2006, Naseer 2010, Blau, 1973, Kimberly, 1976).

According to Blau (1973), the ability of a university or college to recruit good faculty members and good students and to maintain a high academic reputation depends on conditions that in turn depend to a considerable extent on the large scope of the academic enterprise. This is because high academic standing requires specialized academic pursuits in large number of diverse fields, which simply cannot be developed in small colleges (Blau 1973:100). It also requires competing with other institutions for the best faculty and the best students, and financial resources for doing so can rarely be mobilized by a small academic institution (Blau, 1973). Thus, according to Blau (1973), once a top reputation has been achieved, it attracts financial contributions, outstanding students, and great scientists and scholars helping to sustain the elite standing of the academic institution, and at the same time fostering further growth.

Peter Blau (1976) maintain that a physicist in a large department is likely to find colleagues with whom he can collaborate on specific topics. This is because large departments are more likely to have a high energy accelerator, a technical staff, superior libraries, and reprint collection, all of which facilitate research. A specialist in the department promotes a collective emphasis on research rather than on teaching, possibly because it stimulates cosmopolitan contact with outside colleagues, and in this way furthers research efforts on individual faculty (Blau, 1976:538-539).

The diverse areas of interest that exist within the field of administrative sciences do create a fertile ground for social contact and exchange of ideas that stimulate fresh ideas; it does increase the chance that faculty members find congenial colleagues with common academic interests. Finding of congenial colleagues with whom to share specialized academic interests increases with increasing faculty size.

Based on the above discussion, the following hypotheses are presented:

2. There will be a positive and significant relationship between size of faculty and scientific productivity 


\section{Methods}

A total of 557 copies of questionnaires were sent to full time faculty members in Faculties of Administrative Sciences in eleven Universities in Quebec, Canada. Responses were received from 176 faculty members with the number of participants per faculty ranging from 3 to 41. The response rate for participants 32 per cent, rate falling within the 18 to 57 range found in previous studies of universities (See Everett, 1980; McNeece, 1981; Taylor, et.al. 1984)

\subsection{Operational Measures of Variables}

3.1.1 Dependent variable: No single operationalization of scientific productivity will satisfy everyone; invariably, matters of judgment and preference often intrude to compound the problem of measurement. However, the specific dependent variable to which attention is given in this study is the self-reported articles in refereed and non-refereed journals, books, chapters in books, and papers presented or published in refereed conferences during the last five years. ${ }^{1}$

To estimate the validity of the responses, fifty faculty members were randomly selected from our sample, and their self-reported number of publications was compared with counts from the journals indicated from the same five -year period. Forty eight out of the 50 (96 per cent) responses were accurately identified, suggesting that the data were adequate for our purpose.

The measure of scientific productivity was derived from answers to the following questions: Please indicate the number scholarly publications or presentations on which your name appears as the sole author in the last five years. Please indicate the number of publications in which your name appears as one of two or authors in the last five years. Because of the difficulty of establishing singular responsibility for joint publication, no differentiation was made in establishing scientific productivity.

For this study, it was assumed that factors influencing article and book publications are not identical. It was therefore decided to perform separate but parallel analyses of article and book publications. Total articles were operationalized as the summation of all single-and multiple authored articles, chapters in books and papers published or presented in refereed conferences. A chapter in a book was regarded as equivalent to an article. Total books included the summation of single and multiple authored books

\subsubsection{Independent variables.}

Colleague context and faculty size are the independent variables.

Colleague context: The measure of colleague context was derived from answers to the following questions: "As a general rule, how often do you communicate with colleagues in your faculty on research -related matters?" "About how many colleagues in your faculty do you work with closely to exchange detailed information on research- related matters that are of benefit to you or to them?"

Faculty size: This is measured as the total number of full-time faculty members.

\section{Analyses}

The data were grouped for the whole population. Two separate but parallel analyses were performed on the scientific productivity variables. That is all the single authored and multi-authored publications (except single and multi-authored books) were combined to form one production measure. All technical papers were excluded from the analysis. These are publications which are not diffused externally. The second measure included all single and multi-authored books.

Hypotheses 1 and 2 were tested using multivariate regression analysis.

\subsection{Results}

Hypothesis 1 states that there is a positive and significant relationship between contacts with colleagues on research related matters and scientific productivity.

Our result shows no statistically significant relationship between total article and total book production (beta $=1.24$ and 0.08 , respectively; n.s.). A further analysis on single -authored publication production measures, however, shows positive and significant relationship between contacts with colleagues and single authored articles in refereed journals (beta $=0.38, \mathrm{P} \leq 0.05)$, multiple authored articles in refereed journals $($ beta $=0.72, \mathrm{P}$ $<0.05$ ) and multiple authored chapters in books (beta $=0.05, \mathrm{P}<0.01$ ).

It is not entirely surprising that when other determinants of scientific productivity are controlled, contacts with colleagues on research related matters seem not to be statistically significant for both total article and total book production. There are several possible explanations for this non-significant relationship. To begin with, faculty members who are not particularly satisfied with their career opportunities within the university would probably be keeping an eye on outside opportunities. For them, exchange of intellectual ideas might not be particularly important.

Second, contacts with colleagues may be counter-productive if there is no heterogeneity of intellectual interests among colleagues. 
Finally, the operation of the "Matthew effect 3 " presents a paradox. The very qualities of faculty members that make them attractive colleagues also make them less committed to their local institutions or universities because they are always in constant demand by the wider community. This invariably reduces their contacts with colleagues within their own institutions. The source of this paradox is the academic prestige system. As Blau (1973) posits, scholars whose accomplishments are well known in the wider academic discipline are respected colleagues, and their presence increases the allegiance of others to an institution, but they themselves are less dependent on and attached to their local institutions. By the same token, faculty members whose limited academic reputation restricts their opportunities and strengthens their allegiance to the local institution are fewer desirable colleagues (Blau, 1973:127).

Hypothesis 2 states that there will be a positive and significant relationship between faculty size and scientific productivity.

The multivariate regression analysis in Table 1 shows no significant relationship between faculty size and total articles and books production, respectively (beta $=0.00$, n.s.). the analysis was extended to include total single-authored publication production measures (See Table 2). As the table reveals, a positive and significant relationship was found between faculty size and the production of single authored chapters in books (beta $=0.29$, $\mathrm{P}<.01)$ although the rest of the single authored scientific production measures were not statistically related to size. No significant relationship was found between faculty size and the production of multiple authored publications (see Table 3).

The nonsignificant relationship between faculty size and publication production may among other things, be due to the following reasons:

Size has no effect on publication production if the faculty member is in a faculty that does not appreciate the importance of publication. The nonsignificant results may therefore be because the faculty members in the present study are not under pressure to publish.

As pointed out earlier in this study, academic specialties in the faculty of Administrative sciences like any other faculty in the university are not directly interdependent. Each faculty member can therefore pursue publication work independently of the work of others. It is reasonable to conclude that other factors must combine with size for size to be a predictor of publication production.

Table 1 Multivariate Analyses of Global Publication Production Measures on Gender and Age Variables (N- 176)

\begin{tabular}{|l|l|l|l|l|}
\hline Scientific Productivity Measures & Total Single Articles & Total multiple Articles & Total Articles & Total Books \\
\cline { 1 - 4 } & & & & \\
\hline & B- Weights & & \\
\hline Colleague context & 0.25 & B- Weights & B- Weights & B- Weights \\
\hline Faculty size & 0.53 & 0.99 & 1.24 & 0.08 \\
\hline Intercept & -4.04 & 0.75 & 0.49 & 0.33 \\
\hline $\mathrm{R}^{2}$ & $.34^{* * *}$ & 1.33 & -5.37 & 1.17 \\
\hline $\mathrm{F}$ & 1.84 & $.41^{* * *}$ & $.48^{* * *}$ & $.29^{*}$ \\
\hline
\end{tabular}

${ }^{0} \mathrm{p}<0.1, * \mathrm{p}<.05, * * \mathrm{p}<.01 * * * \mathrm{p}<.001$ d.f: degree of freedom $=125^{\mathrm{a}}=$ non standardized

Table 2 Multivariate Analyses of Single Publication Production Measures on Gender and Age Variables (N-176)

\begin{tabular}{|c|c|c|c|c|c|c|}
\hline \multirow[t]{2}{*}{$\begin{array}{l}\text { Scientific } \\
\text { Measures }\end{array}$} & $\begin{array}{l}\text { Articles } \\
\text { in ref. Jrn. }\end{array}$ & $\begin{array}{l}\text { Articles in } \\
\text { non ref.jrn. }\end{array}$ & Books & $\begin{array}{l}\text { Chap. in } \\
\text { Books }\end{array}$ & $\begin{array}{l}\text { Papers } \\
\text { pub. in } \\
\text { ref. conf. }\end{array}$ & $\begin{array}{l}\text { Paper presented } \\
\text { at ref. conf. }\end{array}$ \\
\hline & $\begin{array}{l}\text { B- } \\
\text { Weights }\end{array}$ & $\begin{array}{l}\text { B- } \\
\text { Weights }\end{array}$ & $\begin{array}{l}\text { B- } \\
\text { Weights }\end{array}$ & $\begin{array}{l}\text { B- } \\
\text { Weights }\end{array}$ & B-weight & B-weight \\
\hline Colleague Context & $0.38^{*}$ & 0.28 & 0.03 & 0.02 & 0.16 & 0.04 \\
\hline Faculty size & -0.03 & -0.01 & -0.10 & $0.29 * *$ & .06 & 0.00 \\
\hline Intercept & 1.79 & .59 & .50 & .29 & -1.26 & -4.38 \\
\hline $\mathrm{R}^{2}$ & $.32 *$ & .26 & .26 & 27 & .27 & .25 \\
\hline $\mathrm{F}$ & 1.25 & .50 & .80 & .98 & .85 & .45 \\
\hline
\end{tabular}

${ }^{0} \mathrm{p}<0.1, * \mathrm{p}<.05, * * \mathrm{p}<.01 * * * \mathrm{p}<.001$ d.f: degree of freedom $=125 \mathrm{a}=$ non standardized 
Table 3 Multivariate Analyses of Multiple Authored Publication Production Measures on Gender and Age Variables (N- 176)

\begin{tabular}{|l|l|l|l|l|l|l|}
\hline $\begin{array}{l}\text { Scientific Productivity } \\
\text { Measures }\end{array}$ & $\begin{array}{l}\text { Articles } \\
\text { in ref. Jrn. }\end{array}$ & $\begin{array}{l}\text { Articles in } \\
\text { non ref.jrn. }\end{array}$ & Books & $\begin{array}{l}\text { Chap.in } \\
\text { Books }\end{array}$ & $\begin{array}{l}\text { Papers } \\
\text { pub. in } \\
\text { ref. conf. }\end{array}$ & $\begin{array}{l}\text { Paper presented } \\
\text { at ref. conf. }\end{array}$ \\
\cline { 2 - 7 } & $\begin{array}{l}\text { B- } \\
\text { Weights }\end{array}$ & $\begin{array}{l}\text { B- } \\
\text { Weights }\end{array}$ & $\begin{array}{l}\text { B- } \\
\text { Weights }\end{array}$ & $\begin{array}{l}\text { B- } \\
\text { Weights }\end{array}$ & B-Weight & B-Weight \\
\hline Colleague context & $0.72^{*}$ & 0.35 & 0.06 & $.05^{*}$ & 0.08 & -0.02 \\
Faculty size & 0.04 & 0.01 & 0.33 & 0.14 & .90 & 0.62 \\
\hline Intercept & 2.82 & .07 & .67 & 2.13 & -4.38 & -1.97 \\
\hline $\mathrm{R}^{2}$ & $0.41^{* * *}$ & $0.32^{*}$ & $0.31^{*}$ & $0.36^{* *}$ & $.30^{*}$ & $.33^{*}$ \\
\hline $\mathrm{F}$ & 2.07 & 1.20 & 1.10 & 1.39 & 1.05 & 1.24 \\
\hline
\end{tabular}

${ }^{0} \mathrm{p}<0.1, * \mathrm{p}<.05, * * \mathrm{p}<.01 * * * \mathrm{p}<.001$ d.f: degree of freedom $=125 \mathrm{a}=$ non standardized

\section{Conclusion}

The relationships reported in this paper underscore the multiplicity of the factors which influence the production of publications. Colleague context and faculty size appear to have considerably less impact upon scientific productivity than has generally been accepted. This may be because academic specialties in the Faculties of Administrative Sciences like any other faculty in the university are not directly interdependent. Each faculty member can therefore pursue his or her publication work independently of the work of others. Also, interaction with colleagues and faculty size will not have any effect on publication production if the faulty member does not have interest in publication production.

The fact that there was no significant relationship between colleague context and size on scientific productivity presents serious implications for university decision makers. Universities that place more emphasis on teaching at the expense of research production will score low in their ranking. This is because research volume and research influence are among the performance indicators in the ranking of universities worldwide. The present study focused on scholars in administrative sciences. Further study should be conducted on scholars in different field and society, using the same hypotheses.

\section{Notes}

${ }^{3}$ The name "Matthew effect" was coined by Robert Merton (1968) in his work, "The Matthew effect in science," Science, Vol. 159 (January), pp.56-63. It takes its name from the parable of the talent in Matthew 13, verse 12. "For unto him who has will more be given, and he will have abundance; but form him who has not, even what he has will be taken way."

4 The time parameter 2008- 2013 was chosen for two reasons. First, to eliminate the cumulative effect of sheer professional age on scientific productivity; second, the acceptable form of publication in a discipline may change over time, meaning that a scholar entering a discipline at a particular time may have a large number of one kind of publication. It was therefore assumed that any period longer than five years would not adequately reflect current levels of output.

Scientific productivity of faculty members who have been in the university for less than five years were adjusted to account for the five-year period. This was adjusted as follows: Total number of publications $x 5$ years/number of years in the academic profession.

\section{References}

Anderson, C. and Murray, J. D. (1971) The Professors: Work and Lifestyles Among the Academicians. Cambridge, Mass: Schenkman.

Blau, J. R. (1976) "Scientific Recognition: academic Contest and Professional Role, "Social Studies of Science, Volume 6, pp. 533-545.

Blau, P.M. (1973) The Organization of Academic Work: New York: John Wiley and sons

Carayol, N. and Matt, M. (2006) "Individual and Collective Determinants of Academic Scientists' Productivity," Information Economics and Policy. Vol. 18, Issue 1, (March), pp. 55-72

Collins, H.M. (1983) The sociology of scientific knowledge: Studies of contemporary studies. Annual Review of Sociology, vol. 9, 265-285

Everett, J.E. (1980) "Work Related Attitudes of Academic staff at Australian Universities and Colleges." Journal of Higher education, Volume 2, pp. 271-282.

Glick, W. H. (1985) "Conceptualizing and Measuring Organizational and Psychological Climate: Pitfalls in Multilevel Research” Academy of Management Review, Volume 10, No.3, pp601-616.

Hesli, V.L. and Lee, J. M. (2011) "Faculty research Productivity: Why Do Some of Our Colleagues Publish More than Others?" PS: Political science and Politics. (April). 
Kimberly, J. R. (1976) “Organizational size and the structuralist Perspective: A Review, Critique and Proposal." Administrative Science quarterly, Volume 21, pp.571-597

Kuhn, T. S. (1970) The structure of scientific revolutions. $2^{\text {nd }}$. Chicago, University of Chicago Press

Lodahl, J.B. and Gordon, G. (1972) "The Structure of Scientific Fields and the Functioning of University Graduate departments." American Sociological review, Volume 37, (February), pp. 57-72

Louis, M. R. (1980) "Surprise and Sense -Making: What newcomers Experience in Entering Unfamiliar Organizational settings.” Administrative science quarterly, Volume 25, pp. 226-251.

McNeece, C.A. (1981) "Faculty Publications, tenure and Job Satisfaction in Graduate Social Work Programs." Journal of education for Social Work, Volume 17, pp.13-19

Min, L. and Yong, S. (2014) “Coworker's relation Influence on Individual Job Performance: A Contextualizing Research," Journal of Chemical and Pharmaceutical Research, 6(5), PP.1986-1993

Nasser, M.S. (2010) "Factors Affecting the Job Performance of Academic Staff in the Maldives College of Higher Education." Paper presented at the Second Annual International Research Conference in Social Sciences and Humanities, Bangkok, Thailand.

Nijman, D. Nijhof, W. et al. (2006) "Exploring Differential Effects of Supervisor Support on Transfer of Training." Journal of European Industrial Training, 30 (7), 529-549

Pelz, D. C. \& Andrews, F. M. (1966), Scientists in Organizations. New York: John Wiley and Sons Inc.

Robbins, D. and Johnston, R. (1976) "The Role of Cognitive and Occupational Differentiation in Scientific Controversies." Social Studies of Science, Volume 6, pp.349-368

Schein, E. H. (1971) "Organizational Socialization and the profession of Management.” In D.

Kolb, I. Rubin and J. McIntyre (eds.) Organizational Psychology: A Book of Reading. Englewood Cliffs, N.J. Prentice -Hall

Schepers, P. and Van den BERG, P. (2007) "Social Factors of Work Environment Creativity. Journal of Business and Psychology, 21(3), 407.-428.

Taylor, S. M. et. al. (1984) "Type A Behaviour and Faculty research Productivity: What Are the Mechanisms?" Organizational behaviour and Human performance, Volume 34, pp.402-418

Wanous, J. P. (1980) Organizational Entry: Recruitment, Selection and Socialization of Newcomers. Reading, Ma: Addison-Wesley.

Welsch, D. M. and Zimmer, D. M. (2016) "The Dynamic Relationship Between School Size and Academic Performance: An Investigation of Elementary Schools in Wisconsin." Research in Economics, Volume 70, issue 1 (March), pp. 158-169.

About the authors:

Don Baridam is a Professor of Management with specialization in Organizational Behaviour. He was a former Vice-Chancellor, University of Port Harcourt, and Chairman, Committee of Vice-Chancellors of Federal Universities of Nigeria and also one-time Chairman, Association of Vice-Chancellors of Nigerian Universities. Baridam holds a BSc in Management from University of Wisconsin, an MBA from Northwest Missouri State University, Maryville, United States of America, and a $\mathrm{PhD}$ in Management with specialization in Organizational Behaviour from Laval University, Quebec, Canada. He is a member of the British Institute of Management, Institute of Marketing, London, and a Fellow, Academy of Management, Nigeria.

Letam Don-Baridam is a lecturer at the Faculty of Management Sciences, Rivers State University, Port Harcourt, Nigeria. She holds a Bachelor of Science in Human Resources Management, Kwame Nkrumah University of Science and Technology, Kumasi Ghana, an MSc in Human Resources Management from Brunel University, London and a Ph.D. in Human Resources Management from the University of Port Harcourt. Nigeria. 